\title{
Revisiting the Zimbabwean Unfair Labour Practice Concept
}

\section{P.E.R}

Pioneer in peer-reviewed, open access online law publications

Author

Tapiwa G Kasuso

Affiliation

Zimbabwe Open University,

Harare, Zimbabwe

Email

kasusot@zou.ac.zw

Date Submission

15 October 2020

Date Revised

23 August 2021

Date Accepted

9 September 2021

Date published

8 December 2021

Editor Dr DC van der Linde

How to cite this article

Kasuso TG "Revisiting the

Zimbabwean Unfair Labour

Practice Concept" PER / PELJ 2021(24) - DOI

http://dx.doi.org/10.17159/1727$3781 / 2021 / v 24$ i0a9016

\section{Copyright}

DOI

http://dx.doi.org/10.17159/1727-

3781/2021/v24i0a9016

\begin{abstract}
The 2013 Constitution of Zimbabwe entrenches the broad right to fair labour practices. The right is given effect to in Part III of the Labour Act (Chapter 28:01), which provides an exhaustive list of unfair labour practices which can be committed by employers, trade unions, workers' committees, and other persons. The Labour Act predates the 2013 Constitution. The constitutionalisation of the right to fair labour practices necessarily carries with it the attendant difficulties of reconciling the new rights and the pre-existing regulatory framework. This article seeks to contribute towards a practical understanding of the Zimbabwean unfair labour practice concept in the light of the constitutionalisation of the right to fair labour practices. It explores the nature and scope of the concept of unfair labour practice and examines its relationship with the constitutional right. Further, the contribution critiques the formalistic and conservative approach adopted by the Constitutional Court in explaining this relationship. The article commences with a brief discussion of the origins of the concept and its reception in Zimbabwean labour law. Following from this, the contribution critically analyses the unfair labour practice concept from statutory and constitutional perspectives. It argues for an expanded paradigm of the concept. This can be achieved if the judiciary moves away from pedantic approaches to the interpretation of labour rights. Therefore, the clarion call is for a purposive and expansive interpretation of the right to fair labour practices, which promotes constitutionalism. In addition, the contribution calls upon the legislature to reconsider the viability of the exhaustive list of unfair labour practices in Part III of the Labour Act, given the constitutionalisation of the broad right to fair labour practices.
\end{abstract}

\section{Keywords}

Unfair labour practice; right to fair labour practices; constitutionalism; 2013 Constitution; fairness; Labour Act; employers; employees; trade unions, workers' committees. 


\section{Introduction}

Recently the Constitutional Court of Zimbabwe laid down the requirements that must be satisfied before conduct, positive or otherwise, can be described as an unfair labour practice. ${ }^{1}$ Further, for the first time the court gave meaning to the constitutional right to fair labour practices and explained its relationship with the statutory concept of unfair labour practice. In the light of this development, this contribution revisits the scope and content of unfair labour practices in Zimbabwe. The analysis seeks to evaluate the approach adopted by the Constitutional Court and to contribute towards a practical understanding of the right to fair labour practices as it applies or ought to apply to labour law.

The contribution commences with an overview of the origins of the concept and its reception in Zimbabwean labour law, to put the discussion in context. This is followed by a critical examination of the statutory concept of unfair labour practice. The analysis considers the approach of Zimbabwean courts in interpreting unfair labour practices before the enactment of the 2013 Constitution. Thereafter, the article examines the interplay between the Labour Act (Chapter 28:01) (the LA) and the constitutional right to fair labour practices. The contribution considers whether the concept of unfair labour practice in the LA is a limitation of the constitutional right to fair labour practices, and if so, whether the limitation is reasonable and justifiable in a democratic society.

\section{Retracing the origins of the concept}

The concept of unfair labour practice originated in the United States of America (USA) in the form of the Labour Relations Act, 1935. ${ }^{3}$ The USA concept was a "handy description for a clutch of statutory torts designed to curb employer action against trade unions organizing." ${ }^{4}$ The Wagner Act facilitated the enjoyment of freedom of association by workers whilst at the same time maintaining industrial stability. ${ }^{5}$ In essence, it protected

\footnotetext{
Tapiwa G Kasuso. LLBS LLM LLD. Lecturer, Faculty of Commerce and Law, Zimbabwe Open University, Harare, Zimbabwe. E-mail: kasusot@zou.ac.zw. ORCiD: https://orcid.org/0000-0002-8078-3425. This article is based on sections of the author's LLD thesis.

Greatermans Stores (1979) (Pvt) Ltd v The Minister of Public Service, Labour and Social Welfare (CCZ 2/18) (hereafter the Greatermans case).

Labour Act (Chapter 28:01) (hereafter the LA).

National Labor Relations Act, 1935, also known as the Wagner Act. See Reichman and Mureinik 1980 ILJ 1; Le Roux 2012 Acta Juridica 41.

Landman 2004 ILJ 805.

Newaj Unfair Labour Practice in South African Labour Law 29.
} 
employee rights concerning trade union organisation and collective bargaining and provided remedies for employers' unfair labour practices which interfered with these rights. ${ }^{6}$ The purpose of delineating unfair labour practices was to eliminate "evils thought to exist within the ranks of the industry". ${ }^{7}$ Travis describes these evils as interference by employers in union activities and the blocking of the collective bargaining process. Therefore, at its inception the concept of unfair labour practice was designed to protect workers from undesirable employer conduct in the realm of trade union organising and collective bargaining. ${ }^{8}$ From the USA, the unfair labour practice concept was received into the United Kingdom (UK). ${ }^{9}$ It was incorporated in the UK's Industrial Relations Act, 1971 as unfair industrial disputes. This was narrower than the USA concept in that the Industrial Relations Act only recognised workers' right to join trade unions and participate in their activities and to stand for or hold office in trade unions. Thus, an unfair industrial practice arose when an employer discriminated against or penalised an employee for exercising these rights. ${ }^{10}$ Thereafter, the concept found its way to other jurisdictions, such as India, Japan, Bangladesh, and the Philippines. ${ }^{11}$

In Southern Africa the concept of unfair labour practice was first received in South Africa through the Labour Relations Act 28 of $1956 .{ }^{12}$ It had a meaning that was divorced from its USA roots. Section 1 of the Labour Relations Act, 1956 defined the concept as "any labour practice which in the opinion of the Industrial Court was an unfair labour practice." The concept was wide enough to encompass individual and collective labour practices and its content was left to the Industrial Court to determine and develop on a case-by-case basis. ${ }^{13} \mathrm{~A}$ more refined definition was introduced by the Industrial Relations (Amendment) Act 95 of 1982, followed by the Labour Relations (Amendment) Act 83 of 1988 and the Labour Relations

$6 \quad$ Examples of unfair labour practices included the following: restraint or coercion of employees in the exercise of their organisational rights; interrogation, polls and surveillance; domination and support; discrimination to encourage or discourage union membership; victimisation for participation in unfair labour practice proceedings and refusal to bargain. For a detailed discussion of the Wagner Act see Travis 1948 SMU L Rev 194; Smith 1961 Marq L Rev 223.

Travis 1948 SMU L Rev 194.

Travis 1948 SMU L Rev 194.

Landman 2004 ILJ 805.

10 For a detailed discussion of unfair industrial disputes in the UK see Robertson and Sams 1972 MLR 48; Davies and Freedland Kahn-Freund's Labour and the Law 211. Cooper 2004-2005 CLLPJ 201.

Landman 2004 ILJ 805.

Grogan "Labour Relations" 476. For further discussion of the South African concept of unfair labour practice, also see Grogan Dismissal 86-93; Du Toit et al Labour Relations Law ch 9. 
(Amendment) Act 9 of 1991. The effect of these amendments was to outline a list of specific unfair labour practices. This concept is retained in the current South African Labour Relations Act 66 of 1995, ${ }^{14}$ and in 1996 it was elevated to a constitutional right. ${ }^{15}$

From the above discussion, it can be concluded that the concept of unfair labour practice was designed to protect employees. ${ }^{16}$ It sought to address the inequality of bargaining power inherent in the common law employment relationship. ${ }^{17}$ Grogan argues that the relief for unfair labour practice in the South African context was meant to ensure that employers do not abuse their power to bestow or withhold favours and benefits, or unfairly impose discipline, it was a check on employer unilateralism. ${ }^{18}$ This was achieved by introducing the concept of fairness, which was alien to the common law. ${ }^{19}$ As will be demonstrated in this contribution, Zimbabwe imported the concept from South Africa. ${ }^{20}$ Therefore, where necessary, reliance is placed on the South African jurisprudence for obvious reasons. Zimbabwe and South Africa have entrenched labour rights in their constitutions. ${ }^{21}$ They share the same legal system, which is based on Roman-Dutch common law with an English law influence. Furthermore, they share similar national demographics and endowments, national histories and cultures, and above all, forces of national and international political economy. ${ }^{22}$ Above all, South Africa has since developed an advanced system of labour law such that Zimbabwe can draw useful lessons from its jurisprudence. However, there is a need for caution as the context in which the unfair labour practice concept operates in South Africa is slightly different from that in Zimbabwe. The Labour Relations Act 66 of 1995 of South Africa applies to all sectors

14 Section 186(2) of the Labour Relations Act 66 of 1995 defines the term as follows:

"(2) Unfair labour practice means any unfair act or omission that arises between an employer and an employee involving: (a) unfair conduct by the employer relating to the promotion, demotion, probation (excluding disputes about dismissals for a reason relating to probation) or training of an employee or relating to the provision of benefits to an employee; (b) the unfair suspension of an employee or any other unfair disciplinary action short of dismissal in respect of an employee; (c) a failure or refusal by an employer to reinstate or re-employ a former employee in terms of any agreement; and (d) an occupational detriment, other than dismissal, in contravention of the Protected Disclosures Act, 2000 (Act 26 of 2000), on account of the employee having made a protected disclosure defined in that Act." Section 23(1) of the Constitution of the Republic of South Africa, 1996 provides that everyone has the right to fair labour practices.

Van Niekerk et al Law@work 183-217.

Tsabora and Kasuso 2017 ILJ 46.

Grogan Employment Rights 98.

Grogan Employment Rights 98.

Tsabora and Kasuso 2017 ILJ 47.

Kasuso and Madebwe 2021 AHRLJ 564.

Kasuso 2018 ILJ 1415. 
and does not differentiate between public and private sector employees. ${ }^{23}$ Zimbabwe has a two-tier labour law regime. ${ }^{24}$ Its Labour Act applies only to the private sector with the public sector covered by the Public Service Act (Chapter 16:04) and the Health Service Act (Chapter 15:16).

\section{The reception of the concept in Zimbabwe}

Zimbabwe gained its independence from Britain in April 1980. Before its independence, employment was generally regarded as a private law matter. As such, labour rights were protected mainly under the Roman-Dutch common law. No legal recourse was available against unfair labour practices in any form as the common law contract of employment confers no inherent right to fairness. ${ }^{25}$ Independence brought a paradigm shift in the role of the State in the protection of workers' rights. The new government was determined to introduce socio-economic reforms to placate the masses, who were aggrieved by the debilitating effects of colonialism. ${ }^{26}$ This was achieved through the turn to constitutionalism. To this end, the early social, economic and political transformation of Zimbabwe was predicated on the turn to the Constitution of Zimbabwe, 1980 which contained a justiciable Declaration of Rights. ${ }^{27}$ However, the 1980 Constitution did not guarantee the right to fair labour practices. It entrenched only rights which impacted indirectly on labour law, such as the right to freedom from forced labour, ${ }^{28}$ protection from discrimination, ${ }^{29}$ freedom of assembly and association, ${ }^{30}$ equality and protection of the law, ${ }^{31}$ and protection from inhuman and degrading treatment. ${ }^{32}$

Beyond this, and in what seemed to be acceptance of the fact that the protection of workers' rights, was critical, in June 1980 Zimbabwe joined the International Labour Organisation (ILO). It embarked on a programme of ratification of the fundamental ILO conventions, and this created international obligations which required the alignment of domestic legislation to give full effect to these obligations. And indeed, based on these obligations the State set about enacting labour legislation that repealed all

Rycroft 1996 S Afr Hum Rts Yrbk 141.

Madhuku Labour Law in Zimbabwe 5.

Van Niekerk et al. Law@work 183.

Gwisai Labour and Employment Law in Zimbabwe 36.

Kasuso and Madebwe 2021 AHRLJ 564.

Section 14 of the Constitution of Zimbabwe, 1980.

Section 23 of the Constitution of Zimbabwe, 1980.

Section 21 of the Constitution of Zimbabwe, 1980.

Section 18 of the Constitution of Zimbabwe, 1980.

Section 15 of the Constitution of Zimbabwe, 1980. 
the remnants of the oppressive colonial legislation. ${ }^{33}$ Notable early labour legislation included the Minimum Wages Act, 1980 and the Employment Act, 1980. These statutes established minimum conditions of employment, bestowed on the Minister of Labour the power to enact regulations covering all aspects of employment, and prohibited summary dismissal. ${ }^{34}$

For all this progress, however, the fact that these rights were not constitutionally protected and were protected in several statutes resulted in the fragmentation of laws. ${ }^{35}$ This made it difficult for citizens to effectively protect their labour rights. Besides, the concept of unfair labour practice remained absent from these statutes. Labour legislation did not in any meaningful manner make provision for the fairness of labour practices and the conduct of employers towards employees. Furthermore, the spectre of the colonial era characterised by a dominant capitalist ideology continued to dog the young democracy. ${ }^{36}$ As a result, calls for a better framework arose. In response, the State borrowed from the common law, international labour standards, and comparative jurisdictions such as South Africa and enacted a more comprehensive piece of labour legislation titled the Labour Relations Act 16 of $1985 .{ }^{37}$ This signified the codification of individual and collective labour rights under the overarching concept of unfair labour practices. The turn to the codification of the concept made labour rights easier to identify and made it effortless for any concerned party to assert them. Importantly, the concept of unfair labour practice in the Labour Relations Act 16 of 1985 (the LRA, 1985) is still maintained in the current Labour Act, which is the mainstay of Zimbabwean labour law.

\section{The Labour Act and the concept of unfair labour practice}

The LRA, 1985 was renamed the LA in 2002. ${ }^{38}$ The LA defines the fundamental rights of employees and gives effect to the obligations incurred by Zimbabwe as a member state of the ILO. ${ }^{39}$ Policymakers sought to define and specify unfair labour practices and regulate conditions of employment and other related matters. By defining and specifying unfair labour practices, the legislature enhanced the protection of employees and provided certainty

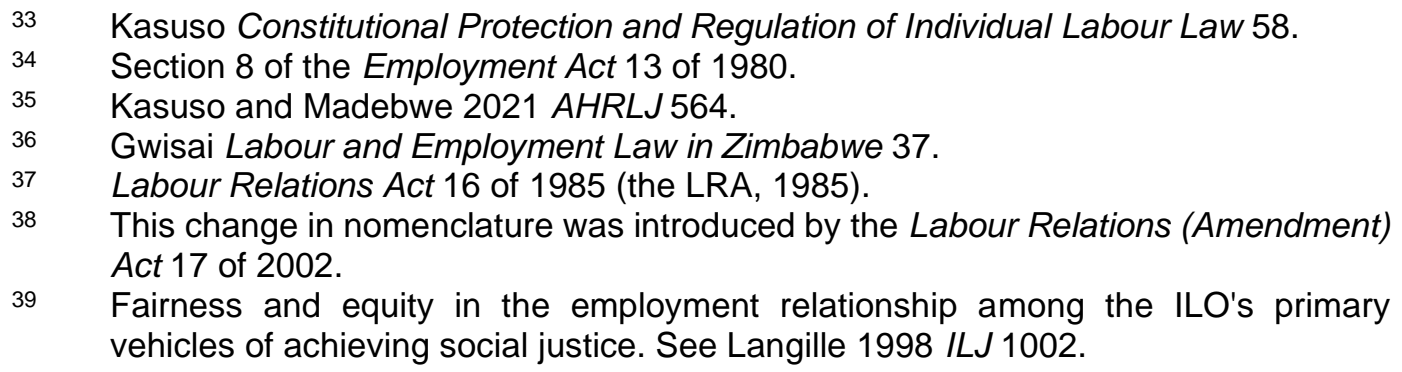


in the law. The statutory concept of unfair labour practice must be interpreted in line with the stated purpose of the LA, ${ }^{40}$ which is to advance social justice and democracy in the workplace by fulfilling the following primary objects:

(a) giving effect to the fundamental rights of employees provided for under Part II;

(b)

(c) providing a legal framework within which employees and employers can bargain collectively for the improvement of conditions of employment;

(d) the promotion of fair labour standards;

(e) the promotion of the participation of by employees in decisions affecting their interests in the workplace;

(f) securing the just, effective, and expeditious resolution of disputes and unfair labour practices. ${ }^{41}$

In codifying unfair labour practices, the legislature sought to give effect to the legislature's objective of promoting fair labour standards at the workplace. The scope and nature of unfair labour practices in the LA must therefore be understood in this context.

\subsection{Defining unfair labour practices}

One notable feature of the LA is that it prescribes a general definition of unfair labour practice. Section 2 of the Act defines an unfair labour practice as "an unfair labour practice specified in Part III or declared to be so in terms of any other provision of the Act." There can be no doubt that an unfair labour practice must be specifically described as such by the LA. If a practice is not specified or described as such in the LA, an employee cannot raise it as an unfair labour practice under the Act. ${ }^{42}$

\subsubsection{The scope of unfair labour practices}

The LA sets out to strike a balance between providing a level of protection to employees, which is required, while at the same time demarcating the types of practices that deserve statutory protection. ${ }^{43}$ The Act, in Part III, makes provision for four types of unfair labour practices, namely those

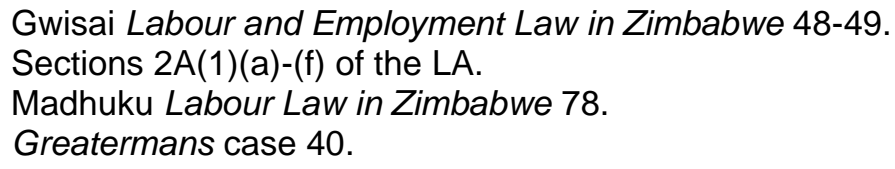


committed by employers, trade unions, workers' committees, and other persons. These cover both individual and collective labour practices. Additionally, section 10 of the LA gives the Minister of Labour powers to prescribe by statutory instrument further acts or omissions which constitute unfair labour practices. To show the extent of the definition of unfair labour practices, Part III of the LA, which is titled "Unfair labour practices", must be set out extensively.

The first two categories of unfair labour practices under Part III of the LA are unfair labour practices that can be committed by employers and other persons. These include the following acts or omissions: preventing, hindering or obstructing an employee in the exercise of any right conferred upon him in terms of Part II of the $L A ;{ }^{44}$ contravening any provision of Part II or section eighteen of the $L A ;{ }^{45}$ refusing to negotiate in good faith with a workers' committee or a trade union which has been duly formed and which is authorised in terms of the LA to represent any employees; refusing to cooperate in good faith with an employment council on which the interests of any of its employees are represented; failure to comply with or to implement a collective bargaining agreement or a decision or finding of an employment council or any decision, finding and determination made under the LA; bargaining collectively or dealing with another trade union, where a registered trade union representing its employees exists; demanding from any employee or prospective employee any sexual favour as a condition of the recruitment for employment, the creation, classification or abolition of jobs or posts, the improvement of the remuneration or other conditions of employment of the employee, the choice of persons for jobs or posts, training, advancement, apprenticeships, transfer, promotion and retrenchment, the provision of facilities related to or connected with employment and any other matter relating to employment and engaging in unwelcome sexually determined behaviour towards any employee, whether verbal or otherwise, such as making physical contact or advances, sexually coloured remarks, or displaying pornographic materials in the workplace. ${ }^{46}$

Unfair labour practices that can be committed by workers' committees and trade unions are prescribed in section 9 of the LA, and these include the following: preventing, hindering or obstructing an employee in the exercise

44 Part II of the LA affords employees the following fundamental labour rights: the right to membership of trade unions and workers committees (s 4); prohibition of forced labour (s 4A); the right of employees not to be discriminated against (s 5); the right to fair labour standards (s 6 ) and the right to democracy in the workplace.

45 Section 18 of the LA protects the right of female employees to paid maternity leave.

46 Sections $8(a)-(h)$ of the LA. 
of any right conferred upon him in terms of Part II of the LA; contravening any of the provisions of the constitution of a workers committee or trade union; failing to represent an employee's interests concerning any violation of his rights under the LA or under a valid collective bargaining agreement, or under a decision or finding of an employment council; failing to comply with or to implement any decision or finding of an employment council or any decision or finding made under Part XII of the LA, or any determination or direction under the LA which is binding upon it; not being registered and purporting to act as a collective bargaining agent in terms of Part $X$ of the LA or participating in the collection of union dues; recommending collective job action in contravention of a valid collective bargaining agreement; purporting to act as the collective bargaining agent for employees, or calls for collective job action when another trade union has duly been registered to represent the employees concerned; and purporting to enter upon an agency agreement or collective bargaining agreement when another trade union has been duly registered for the workers concerned.

From the foregoing, sections 8 and 9 of the LA define unfair labour practices by reference to acts or omissions of employers, trade unions, workers' committees, and other persons. As for unfair labour practices arising from employer acts or omissions, these can be committed against employees, trade unions, workers' committees, and Employment Councils. Unfair labour practices by trade unions and workers' committees can be committed against employees and other trade unions. Therefore, the concept of unfair labour practice in the LA protects employees and their collective organs engaged in the employment relationship. The use of the term labour practice also indicates that the practice must arise within the employment relationship. ${ }^{47}$ On this basis, protections afforded by unfair labour practices do not extend to independent contractors. ${ }^{48}$ However, some of them extend beyond the employment relationship and apply to prospective employees and can be committed by any other person. ${ }^{49}$ Furthermore, the notion of labour practice refers to unfair conduct by the employer, trade union, or workers' committee, which can be a single act or omission. The act or omission must have occurred and not merely be anticipatory. ${ }^{50}$ It must relate to the specific unfair labour practices listed in Part III of the Labour Act. In the light of the foregoing, the list of unfair labour practices falling within the

\footnotetext{
$47 \quad$ Van Niekerk et al. Law@work 186.

48 Section 2 of the LA defines an employee for the purposes of the LA and excludes independent contractors from the application of the Act.

49 For instance, s 8(g) of the LA applies to applicants for jobs.

$50 \quad$ Van Niekerk et al. Law@work 187.
} 
statutory definition of the term is exhaustive. ${ }^{51}$ The definition is clear that to be an unfair labour practice an act or omission must be specifically described as such by the Act. ${ }^{52}$

\subsubsection{Approaches to practices falling outside the statutory definition}

There are notable omissions from the list of unfair labour practices in Part III of the LA. Not all incidents of employer power have been enumerated. For instance, at the level of the individual employee, unfair conduct by employers relating to promotion, transfers, and unilateral changes to the terms and conditions of employment are not covered by the concept of unfair labour practice. ${ }^{53}$ This does not mean that victims of unfair employer conduct not covered by the unfair labour practice concept are remediless. Zimbabwean courts have fashioned remedies based on common law principles. For instance, in Guruva $v$ Traffic Council of Zimbabwe ${ }^{54}$ the Appellant was notified by the Respondent that he was to be transferred to another town. He wrote back making submissions against the transfer and giving personal reasons for objecting to the transfer. The Respondent considered the submissions and advised that its decision to transfer him stood. Aggrieved by the decision, the Appellant approached the court, arguing that the decision to transfer him was unfair in that the Respondent failed to observe the audi alteram partem rule. ${ }^{55}$ The Supreme Court of Zimbabwe held that transferring an employee without allowing him to be heard was an unfair practice. In casu the court was satisfied that the Appellant had been given an opportunity to make representations against the transfer. Furthermore, the court held that although an employer had the right to transfer an employee, the employer's discretion is not to be readily interfered with except for good cause shown. The term good cause would include failure to give an employee an opportunity to be heard, unfounded allegations, victimisation, action taken to disadvantage an employee, and if the decision is unreasonable and actuated by bad faith. ${ }^{56}$ Further, unilateral changes to terms and conditions of employment by employers have been

$51 \quad$ Madhuku Labour Law in Zimbabwe 78.

$52 \quad$ Muwenga v PTC 19972 ZLR 483 (S); Nyamande v Zuva Petroleum (Pvt) Ltd 2015 2 ZLR 157 (S); City of Gweru v Munyari (62/04) (SC 15 of 2005, Civil Appeal 162 of 2004) [2005] ZWSC 15 (01 June 2005); Mudarikwa v Director of Housing and Community Services 20071 ZLR 41 (S).

53 Kasuso and Madebwe 2021 AHRLJ 565.

$54 \quad$ Guruva v Traffic Safety Council of Zimbabwe 20091 ZLR 58 (S).

55 It is an elementary notion of fairness and justice that a decision must not be made against a person without affording him or her an opportunity to be heard.

56 Taylor v Minister of Higher Education 19962 ZLR 772 (S); Sagandira v Makoni Rural District Council (SC 70 of 2014, Civil Appeal SC 264 of 2012) [2014] ZWSC 70 (15 September 2014); Rainbow Tourism Group v Nkomo 20152 ZLR 248 (S). 
successfully challenged under the common law as breaches of contract. ${ }^{57}$ In Agricultural Bank of Zimbabwe Ltd t/a Agribank $v$ Machingaifa ${ }^{58}$ employees were entitled to the payment of a mileage allowance of 4000 kilometres per month calculated at the Automobile Association of Zimbabwe rates. This contractual benefit was unilaterally varied by the employer on the basis that it was now too expensive for it to be sustained. The court held that under the common law a party to a contract cannot unilaterally alter its terms and conditions without the consent of the other party. The decision by the bank was set aside, based on a breach of contract and not as an unfair labour practice..$^{59}$

Other unfair employer conduct not covered by the LA includes unfair conduct relating to probation, training and benefits, and unfair disciplinary action short of dismissals such as demotions and suspensions. Although it might be unnecessary to have an unfair labour practice relief if a remedy is available under the common law, it is submitted that the common law has its limitations. ${ }^{60}$ The common law is concerned mainly with the lawfulness of employer conduct and does not intrude into the substantive fairness of the conduct. The concept of unfair labour practice must be a charter of rights for all and its reach must be broadened. To this end, there is a need to balance employers' right to direct their business as they deem fit, and the protection of employees. ${ }^{61}$ With the enactment of the 2013 Constitution, which entrenches the broad right to fair labour practices, it may be time to rethink the purpose of keeping an exhaustive list of unfair labour practices in the LA. It is therefore necessary at this point to analyse the constitutional right to fair labour practices and its relationship with the statutory concept of unfair labour practices.

\section{The 2013 Constitution}

On 22 of May 2013, Zimbabwe enacted a new Constitution entitled the Constitution of Zimbabwe (Amendment) Act 20 of 2013. This Constitution is a marked departure from the typical Westminster model Constitution of

$57 \quad$ Madhuku Labour Law in Zimbabwe 78.

$58 \quad$ Agricultural Bank of Zimbabwe Ltd v Machingaifa 20081 ZLR 244 (S).

59 For further cases dealing with the unilateral variation of contracts of employment see Air Zimbabwe (Pvt) Ltd v Zendera 20021 ZLR 132 (S); Chirasasa v Nhamo 20032 ZLR 206 (S); Stewart $v$ The Vice-Chancellor of the University of Zimbabwe (SC 97/01).

$60 \quad$ Cheadle 2006 ILJ 663.

$61 \quad$ Cheadle 2006 ILJ 663. 
$1980 .{ }^{62}$ For instance, Chapter 1 of the 2013 Constitution is dedicated to founding provisions, amongst which feature the supremacy of the Constitution and founding values and principles. Chapter 2 sets out the national objectives which establish principles of State policy. To give effect to the principles, values, and national objectives of the Constitution, an essential feature of the Constitution is the Declaration of Rights. It entrenches fundamental human rights and freedoms, which include socioeconomic rights. Significantly, the 2013 Constitution introduces for the first time in Zimbabwe's constitutional history a Declaration of Rights that entrenches labour rights as socio-economic rights. Section 65(1) of the Constitution provides that every person has the right to fair and safe labour practices and standards and to be paid a fair and reasonable wage. Other labour rights entrenched in section 65 of the Constitution include the following: the right to trade union organisation; 63 the right to participate in collective job action; 64 employees right to just, equitable and satisfactory conditions of work; ${ }^{65}$ the right to engage in collective bargaining; 66 the right to equal remuneration for similar work ${ }^{67}$ and female employees' right to fully paid maternity leave for three months. ${ }^{68}$

These rights seek to provide redress to the social injustices that were experienced between 2000 and 2009. During this period Zimbabwe experienced a serious economic and political crisis which was characterised by hyperinflation, liquidity challenges, political violence, and rampant violation of workers' rights. ${ }^{69}$ Thus, the constitutional entrenchment of rights and freedoms represents a milestone in the development of society, more particularly as it can be seen as reflecting the social, economic, and political priorities that society would have chosen. ${ }^{70}$ Indeed, the constitutional

62 It was accepted that the 1980 Constitution had become outdated, bulky, unclear and inaccessible. It had been amended a record nineteen times and had been in existence for three decades. In addition, it had been drafted as a document to transfer power from colonial Rhodesia to the people of Zimbabwe on independence in 1980. Therefore, there was a need for a home-grown Constitution which was people driven, inclusive and democratic. See Madebwe 2014 Midlands State U L Rev 6.

63 Section 65(2) of the Constitution of Zimbabwe Amendment (No 20) Act 2013 (the 2013 Constitution).

64 Section 65(3) of the 2013 Constitution.

65 Section 65(4) of the 2013 Constitution.

66 Section 65(5) of the 2013 Constitution.

67 Section $65(6)$ of the 2013 Constitution.

68 Section 65(7) of the 2013 Constitution.

69 The High Court of Zimbabwe also took judicial notice of the prevailing economic conditions in the case of Samanyau v Fleximail (Pvt) Ltd (HH 108/11) in which it abandoned the principle of currency nominalism. Van Marle 2009 Stell LR 286; Roux 2009 Stell LR 258. 
protection of rights and freedoms provides a mirror to determine the progress of society concerning the achievement of the rule of law and the elevation of the rights of traditionally downtrodden social classes. ${ }^{71}$

Zimbabwean labour law is now grounded on a rights-based model of constitutionalism with the hope that there would be greater protection of workers. ${ }^{72}$ Firstly, the importation of constitutional values into the workplace provides a useful model of conceptualising how labour law should develop. It enhances the legitimacy of workers' demands for protection and gives credence to policymaking. ${ }^{73}$ Secondly, constitutionalising labour rights has the potential of humanising the workplace by removing the workplace from the clutches of the libertarian perspective of labour law. ${ }^{74}$ Not only does it advance social justice at the workplace by balancing the power between labour and capital, but it also improves the quality of life of workers. They tend to enjoy greater job security, basic norms of fairness, and proportionality. ${ }^{75}$ However, the realisation of constitutional rights by workers is largely dependent on the interpretational approaches and techniques of the rights by the courts.

\subsection{The constitutional right to fair labour practices}

Section 65(1) of the Constitution guarantees in a wholesome fashion the right to fair labour practices. This is an unusually broad right not capable of precise definition and it is not necessary or desirable to define it. ${ }^{76}$ Despite its enigmatic nature, the Constitutional Court of Zimbabwe in the Greatermans case provided a general understanding of the scope and content of the right. This case raised the question of the constitutionality of civil legislation's retrospective effect. The Applicants alleged that section 18 of the Labour (Amendment) Act 5 of 2015 read with section 12C of the Act were unconstitutional. This allegation was predicated on the provision that gave retrospective effect to a new obligation on an employer who terminates a contract of employment on notice to pay the employee whose contract was terminated the minimum retrenchment package of not less than one month's salary for every two years served by the employee. This obligation was retrospectively imposed on all employers who terminated employees'

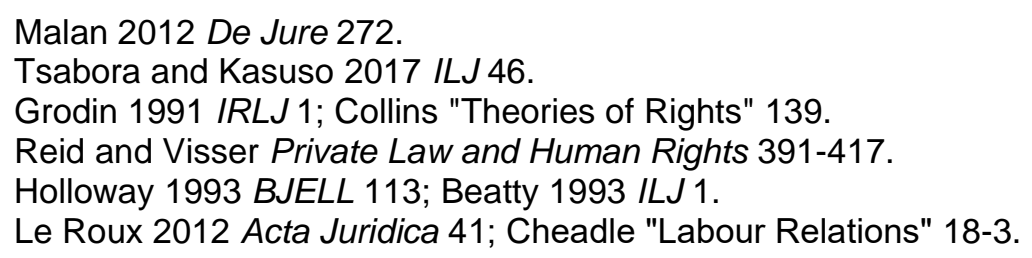


contracts on notice on or after 17 July $2015 .{ }^{77}$ The Applicants argued that section 18 of the Labour (Amendment) Act violated the following fundamental rights: the right to equality, the right to fair labour practices, and the right not to be compulsorily deprived of property. In respect of the right to fair labour practices protected in section 65(1) of the Constitution, the Applicants submitted that the post facto imposition of the financial obligation upon them to pay the employees whose contracts they had terminated on notice the minimum retrenchment package meant that the employees were being paid when they had not rendered any services. Therefore, paying employees who had not worked was an unfair labour practice against employers.

In giving meaning to the constitutional right to fair labour practices the court held that for a person to allege an unfair labour practice as a violation of the right enshrined in section 65(1) of the Constitution, the conduct complained of must constitute one of the acts or omissions listed by the LA as unfair labour practices. The Constitutional Court then laid down the general requirements that must be satisfied before conduct can be held to be an unfair labour practice. It stated as follows:

(i) The 'act or omission' must constitute a 'labour practice'. An 'act' or 'omission' may refer to either a single act or a single inaction which may or may not have lasting consequent and having occurred during the subsistence of the employment relationship, that is, in the period between the conclusion of the contract of employment and its termination. The word 'practice' suggests that the employer must have actually done something or declined to do something.

(ii) The unfair labour practice can arise only if the employer does something or refrains from doing something ('act or omission'). In Zimbabwe the employer must have actually done something listed in Part III of the Act, which act or omission the employee claims the employer should have done or should have refrained from doing.

(iii) The unfair labour practice must be between an employer and an employee. In Zimbabwe, however, the unfair labour practice may be between the employee and a trade union, a workers' committee or any other person for sexual conduct amounting to an unfair labour practice.

(iv) The unfair labour practice must involve one of the practices specified, for our purposes listed in Part III of the Act or declared to be so in terms of any other provision of the Act; and

77 For detailed discussion of the effect of the Labour (Amendment) Act 5 of 2015 on employers' right to terminate contracts of employment on notice, see Kasuso and Manyatera 2015 Midlands State U L Rev 88; Mucheche 2017 ZELJ 16. 
(v) the act or omission complained of must be unfair. ${ }^{78}$

The court concluded that the imposition by the legislature on employers who terminated employees' contracts on notice of the obligation to pay them a minimum retrenchment package was not an unfair labour practice. ${ }^{79}$ The conduct which was being complained of was not the conduct of the employer but the legislature. ${ }^{80}$ Furthermore, the conduct was not specified as an unfair labour practice in the LA. It did not meet the criteria set out above.

The Constitutional Court held that the constitutional right to fair labour practices is limited to the statutory concept of unfair labour practice in the LA. ${ }^{81}$ With due respect, this interpretation is conservative and premised on a formal concept of the rule of law. It does not accord with the constitutional values recognised in the 2013 Constitution, which require the adoption of a substantive concept of the rule of law aimed at protecting fundamental rights and freedoms. Section 46(1) of the Constitution provides that when interpreting the Declaration of Rights, courts must give full effect to the rights entrenched therein and must promote the values and principles that underlie a democratic society. These include openness, justice, human dignity, equality, freedom, and the values and principles set out in section 3 of the Constitution. ${ }^{82}$ In giving meaning to the constitutional right to fair labour practices, the Constitutional Court should have examined the essential elements of the right, namely, every person (beneficiaries of the right), fairness, and labour practice. The court's decision, as shall be demonstrated hereinbelow, should have been based on a broader scope of interpretive premises.

\subsubsection{Beneficiaries of the right to fair labour practices in section 65(1)}

Section 65(1) of the Constitution confers the right to fair labour practices to every person. This is a departure from Part III of the LA, which confers the right against unfair labour practices to specific beneficiaries. It can therefore be questioned whether section 65(1) has broadened the scope of the right beyond the employment relationship. In the Greatermans case, the Constitutional Court held that the reference to every person in section 65(1)

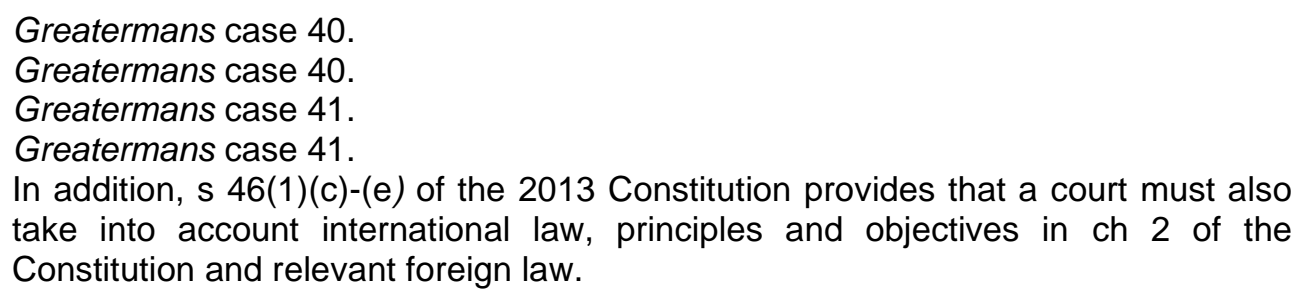


indicates that the right to fair labour practices is claimable by a person in an employment relationship. However, the Court did not provide a jurisprudential basis for this finding. It is submitted that the ambit of section $65(1)$ is qualified by the reference to labour practices. Commenting on section 23(1) of the Constitution of the Republic of South Africa, 1996 which bestows the right to fair labour practices on everyone, Cheadle states that the term everyone must be interpreted with reference to "labour practices". He argues as follows:

\begin{abstract}
Although the right to fair labour practices in subsection (1) appears to be accorded everyone, the boundaries of the right are circumscribed by the reference in subsection (1) to 'labour practices.' The focus of enquiry into ambit should not be on the use of 'everyone' but the reference to 'labour practices.' Labour practices are the practices that arise from the relationship between workers, employers and their respective organisations. Accordingly, the right to fair labour practices ought not to be read as extending the class of persons beyond those classes envisaged by the section as a whole. ${ }^{83}$
\end{abstract}

It follows, therefore, that every person for the purposes of section 65(1) must be limited to an employment relationship or a relationship akin to that. This is the relationship between an individual employee and employer and their collective organs such as workers' committees, trade unions, and employer organisations. However, there is room for the extension of the right beyond the employment relationship. ${ }^{84}$ A labour practice deemed unfair in terms of the statutory concept can be committed by "other persons" than employers, trade unions, and workers committees. Further, in limited circumstances, the statutory concept of unfair labour practice is available to prospective employees. Thus, the constitutional right is broad enough to go beyond the employment relationship to include other players in the labour market.

Since the constitutional right to fair labour practices is claimable by any person in an employment relationship it follows that employers, trade unions, workers' committees, and employer organisations can also be victims of unfair labour practices. Whilst unfair conduct against employers does not amount to unfair conduct under the LA, it can qualify as an unfair labour practice in terms of the Constitution. Acknowledging employer protection in South Africa based on section 23(1) of the Constitution of the

$83 \quad$ Cheadle "Labour Relations" 18-3; Grogan "Labour Relations" 475.

84 Le Roux 2012 Acta Juridica 41 advocates that the unfair labour practice doctrine be reinvented using an expanded paradigm based on the constitutional right to fair labour practices. 
Republic of South Africa, 1996, the Labour Court in National Entitled Workers Union v CCMA ${ }^{85}$ held that:

\begin{abstract}
An employee may, in limited circumstances, commit conduct against an employer that may be lawful but unfair. An employer has the right to expect that in certain circumstances an employee will not merely comply with his or her rights in regard to the employer but will also act fairly. This conduct may, in my view, qualify as an unfair labour practice that is, a practice that is contrary to that contemplated by s 23 of the Constitution.
\end{abstract}

The employers' remedy in these circumstances lies directly with the Constitution and not the LA. The statutory concept of unfair labour practices does not provide employers and employer organisations with a cause of action or remedy for unfair employee conduct. It is a concept that was introduced mainly to provide employees with protection as it was viewed that employers enjoy greater social and economic power than employees. ${ }^{86}$ Whether the LA must provide specific unfair labour practices by employees against employers is debatable.

\title{
5.1.2 The meaning of labour practices in section 65(1)
}

Cooper defines the term labour practices as matters of mutual interest that arise from the employment relationship; that is, the relationship between employers, employees, and their collective organs. ${ }^{87}$ In the Greatermans case the Constitutional Court held that for a person to allege unfair conduct as a violation of section 65(1) of the Constitution, the conduct complained of must constitute one of the acts or omissions listed in Part III of the LA as an unfair labour practice. It is submitted that section 65(1) of the Constitution is broader than the statutory concept of unfair labour practice. This requires a purposive interpretation of the right inspired by constitutional principles and values. The right to fair labour practices does not seek to override or replace the rights provided for in the LA. As a starting point, it must protect unfair labour practices codified in the LA. If a practice is not specified as unfair in the LA, it cannot be raised as an unfair labour practice under the Act but as an infringement of the constitutional right to fair labour practices. ${ }^{88}$ A victim of such an unfair labour practice can raise an action based directly on the Constitution and not the LA. 89

\footnotetext{
85 National Entitled Workers Union v CCMA 20042 BLLR 165 (LC); National Education Health and Allied Workers Union v CCMA 200728 ILJ 1223 (LAC). See Ex parte Chairperson of the Constitutional Assembly: In re Certification of the Constitution of the Republic of South Africa, 1996199617 ILJ 821 (CC).

87 Cooper 2004-2005 CLLPJ 206; Grogan "Labour Relations" 502.

88 Madhuku Labour Law in Zimbabwe 78.

89 Section 85 of the 2013 Constitution.
} 
It must be emphasised that the role of developing further unfair labour practices based on section 65(1) of the Constitution lies with the judiciary. In giving content to the right, courts must be guided by domestic experiences reflected from the jurisprudence generated by the unfair labour practices provisions of the LA. Further, they must seek guidance from international standards, foreign law, and the overall objectives of the LA. Any unfair labour practices developed by the courts must be fashioned in a manner that promotes values and principles that underlie a democratic society. ${ }^{90}$ The notion of labour practices must embrace the protection against unfair conduct relating to work security and employment opportunities and underwrite minimum standards.

\subsubsection{The fairness element of section 65(1)}

In the Greatermans case the Constitutional Court of Zimbabwe also held that for an act or omission to qualify as an unfair labour practice it must be unfair. In other words, the court accepted that the operational principle of section 65(1) of the Constitution is the concept of fairness. The constitutional right to fair labour practices "is essentially about infusing into employment a degree of fairness not guaranteed by the common law." ${ }^{11}$ As stated in the South African case of Association of Professional Teachers $v$ Minister of Education, ${ }^{92}$ this resonates with the values of the Constitution and the obligation that it imposes on courts to integrate and apply the concept of unfair labour practice in a human rights context. In explaining the term fairness in the context of section 23(1) of the Constitution of the Republic of South Africa, 1996, it was held that the focus of the right to fair labour practices is, broadly speaking, "the relationship between the worker and the employer and the continuation of that relationship on terms that are fair to both."93 While the Constitutional Court of South Africa found that fairness depends on the circumstances of a particular case and involves a value judgment, it held that the fairness required by the right to fair labour practices demands striking a balance between the competing interests of employers, employees, and the public. ${ }^{94}$ This approach is referred to by Cooper as the equivalence of interest approach. ${ }^{95}$ It requires that the

\footnotetext{
$90 \quad$ Kasuso Constitutional Protection and Regulation of Individual Labour Law 141.

$91 \quad$ Cohen 2009 ILJ 2273; Le Roux 2014 ILJ 42.

$92 \quad$ Association of Professional Teachers v Minister of Education 199516 ILJ 1048 (IC) 1077. National Education Health and Allied Workers Union v University of Cape Town 2003 24 ILJ 95 (CC).

$94 \quad$ National Education Health and Allied Workers Union v University of Cape Town 2003 24 ILJ 95 (CC). 
concept of fair labour practices recognises the rightful place of equity in the workplace. There can be no fairness where the interests of one party are advanced at the expense of the other, and the concept must also recognise that what is lawful may be unfair. This interpretation of fairness by South African courts is applicable in the Zimbabwean context. Section 65(1) of the Constitution and the LA must be construed in a manner that best promotes the principle of fairness. Nevertheless, the law cannot anticipate the boundaries of conduct which is fair or unfair. The concept of unfair labour practice must be flexible. ${ }^{96}$

\section{The relationship between the Constitution and the Labour Act}

The interplay between the constitutional right to fair labour practices in section 65(1) and the statutory concept of unfair labour practice in Part III of the LA has since been settled by the Constitutional Court in Magurure $v$ Cargo Carriers International Haulers (Pvt) Ltd t/a SABOT. ${ }^{97}$ The Applicants were employed by the Respondent as truck drivers. They approached the Constitutional Court, accusing the Respondent of violating their right to fair labour practices. They alleged that the Respondent required them to work long hours, work overtime without pay, and not to leave their trucks unattended. The Applicants accepted that there was a Collective Bargaining Agreement made in terms of the LA which regulated the unfair employer conduct they had raised. In dismissing the application, the court held that the matter which had been raised by the Applicants was not a constitutional matter. ${ }^{98}$ The conduct complained of was covered by a law of general application. Therefore, where legislation has been enacted to give effect to a right, a litigant should rely on that legislation to give effect to the right in question or challenge the legislation as being inconsistent with the

96 Poolman Principles of Unfair Labour Practice 42 summarises the position as follows: "The concept of unfair labour practice is an expression of the consciousness of modern society of the value of the rights, welfare, security and dignity of the individual groups of individuals in labour practices. The protection envisaged by the legislature in prohibiting unfair labour practices underpins the reality that human conduct cannot be legislated for in precise terms. The law cannot anticipate the boundaries of fairness or unfairness of labour practices. The complex nature of labour practices does not allow for such rigid regulation of what is fair or unfair in any particular circumstance. Labour law practices draw their strength from the inherent flexibility of the concept 'fair'. This flexibility provides a means of giving effect to the demands of modern industrial society for the development of an equitable, systematized body of labour law. The flexibility of 'fairness' will amplify existing labour law in satisfying the needs for which the law itself is too rigid. " 
Constitution. Direct reliance on the Constitution to enforce the right to fair labour practices should be avoided. A litigant may not bypass legislation giving effect to a right and rely directly on the Constitution without challenging the legislation as falling short of the constitutional standard. This is based on the principle of avoidance ${ }^{99}$ and the doctrine of subsidiarity (the concept of one system of law). ${ }^{100}$ These principles are designed to prevent the development of two streams of jurisprudence. ${ }^{101}$

\section{Conclusion}

This contribution has unpacked the scope and nature of the concept of unfair labour practice in the Zimbabwean context. It has also evaluated the relationship between the statutory concept of unfair labour practice and the constitutional right to fair labour practices based on the Greatermans case. The article has established that from its inception the purpose of the concept of unfair labour practice was to protect workers and their collective organs. Further, it was demonstrated that the Zimbabwean concept of unfair labour practice is wide in its application. It covers employees, trade unions, workers' committees, and prospective employees. However, it is limited in its scope. Notable omissions from the list include unfair employer conduct concerning probation, promotion, training, the variation of contracts of employment, training, benefits, and unfair disciplinary action such as demotions and suspensions. Importantly, the study showed that the Constitutional Court of Zimbabwe adopted a narrow and formalistic concept of the constitutional right to fair labour practices vis-a-vis the statutory concept of unfair labour practice. This rule-book approach limits the constitutional right to the exhaustive list of unfair labour practices in Part III of the LA and is an abrogation of the duties of the Constitutional Court in section 176 of the Constitution. Finally, it was established that a litigant cannot bypass the statutory concept of unfair labour practice and rely directly on the broad constitutional right to fair labour practices. Reliance

The principle dictates that remedies should be found in the common law or legislation before resorting to constitutional remedies. See Chawira $v$ Minister, Justice Legal and Parliamentary Affairs (CCZ 3 of 2017, Constitutional Application CCZ 47 of 2015, Constitutional Application CCZ 50 of 2015) [2017] ZWCC 3 (20 March 2017). The doctrine of subsidiarity holds that norms of greater specifity should be relied on before resorting to norms of greater abstraction. See Moyo $v$ Sgt Chacha (CCZ 19 of 2017, Constitutional Application CCZ 73 of 2016) [2017] ZWCC 19 (20 September 2017).

101 See Gcaba v Minister for Safety and Security 20101 SA 238 (CC); MEC for Education, Kwa-Zulu Natal v Pillay 20081 SA 474 (CC); Mushapaidze v St Annes Hospital (CCZ 18 of 2017, Constitutional Application CCZ 20 of 2014) [2017] ZWCC 18 (20 September 2017); Katsande v Infrastructure Development Bank of Zimbabwe 20171 ZLR 670 (C); Du Toit et al. Labour Relations Law 484-485. 
must be placed on the LA to give effect to the right to fair labour practices unless one is alleging that the LA falls short of the constitutional standard.

In conclusion, it is quite clear that the protection of workers' rights in Zimbabwe through the concept of unfair labour practice could be enhanced in two main ways. Firstly, the judiciary could play an active role in the protection of labour rights. While the concept of unfair labour practice in the LA takes a form different from the constitutional right to fair labour practices, the Constitution plays an important role in interpreting these provisions. The key to the greater protection of workers lies in the courts taking the lead to protect these rights based on the tenets of constitutionalism. This calls for the judiciary to interpret the right to fair labour practices broadly, purposively, and in a manner that promotes the values and principles of the 2013 Constitution. Courts should avoid using their discretion to determine unfair employer conduct based on the common law concept of lawfulness. Secondly, the LA should be amended and make provision for unfair labour practices which have been omitted from the Act. Certainty and clarity on the scope and nature of unfair labour practices could be further secured if the LA provides practical guidelines on the standard of fairness that must be applied when considering the fairness of employer conduct not covered by the LA. Alternatively, the Minister of Labour could invoke section 10 of the Labour Act and prescribe by statutory instrument further unfair labour practices omitted in the LA.

\section{Bibliography}

\section{Literature}

Beatty 1993 ILJ

Beatty D "Constitutional Labour Rights: Pros and Cons" 1993 ILJ 1-17

Cheadle "Labour Relations"

Cheadle H "Labour Relations" in Cheadle $\mathrm{H}$ et al South African Constitutional Law: The Bill of Rights (Butterworths Durban 2006) ch 18

Cheadle 2006 ILJ

Cheadle $\mathrm{H}$ "Regulated Flexibility: Revisiting the LRA and the BCEA" 2006 ILJ 663-702

Cohen 2009 ILJ

Cohen T "Implying Fairness into the Employment Contract" 2009 ILJ 22712295 
Collins "Theories of Rights"

Collins $\mathrm{H}$ "Theories of Rights as Justification for Labour Law" in Davidov $\mathrm{G}$ and Langille B (eds) The Idea of Labour Law (Oxford University Press Oxford 2011) 137-155

Cooper 2004-2005 CLLPJ

Cooper C "Right to Fair Labour Practices" 2004-2005 CLLPJ 199-218

Davies and Freedland Kahn-Freund's Labour and the Law

Davies P and Freedland M Kahn-Freund's Labour and the Law (Stevens and Sons London 1983)

Du Toit et al Labour Relations Law

Du Toit D et al Labour Relations Law: A Comprehensive Guide $5^{\text {th }}$ ed (LexisNexis Durban 2015)

Grodin 1991 IRLJ

Grodin RJ "Constitutional Values in the Private Workplace" 1991 IRLJ 1-13

Grogan Dismissal

Grogan J Dismissal, Discrimination and Unfair Labour Practices $2^{\text {nd }}$ ed (Juta Cape Town 2007)

Grogan Employment Rights

Grogan J Employment Rights (Juta Cape Town 2010)

Grogan "Labour Relations"

Grogan J "Labour Relations" in Currie I and De Waal J (eds) The Bill of Rights Handbook $6^{\text {th }}$ ed (Juta Cape Town 2013) 472-515

Gwisai Labour and Employment Law in Zimbabwe

Gwisai M Labour and Employment Law in Zimbabwe: Relations of Work Under Neo-Colonial Capitalism (Zimbabwe Labour Centre Harare 2006)

Holloway 1993 BJELL

Holloway I "The Constitutionalisation of Employment Rights: A Comparative Overview" 1993 BJELL 113-141

Kasuso 2018 ILJ

Kasuso TG "Enforcement of Labour Court Judgments in Zimbabwe: Lessons and Perspectives from Southern Africa" 2018 ILJ 1415-1435 
Kasuso Constitutional Protection and Regulation of Individual Labour Law Kasuso TG Reflections on the Constitutional Protection and Regulation of Individual Labour Law and Employment Rights in Zimbabwe (LLD-thesis University of South Africa 2021)

Kasuso and Madebwe 2021 AHRLJ

Kasuso TG and Madebwe T "The Protection of Individual Labour Rights in Zimbabwe" 2021 AHRLJ 552-572

Kasuso and Manyatera 2015 Midlands State $U$ L Rev

Kasuso TG and Manyatera G "Termination of the Contract of Employment on Notice: A Critique of Nyamande and Another v Zuva Petroleum (Pvt) Ltd SC 43/15" 2015 Midlands State U L Rev 88-106

Landman 2004 ILJ

Landman AA "Fair Labour Practices: The Wiehahn Legacy" 2004 ILJ 805812

Langille 1998 ILJ

Langille BA "Labour Law Is Not a Commodity" 1998 ILJ 1002-1016

Le Roux 2012 Acta Juridica

Le Roux R "The New Unfair Labour Practice" 2012 Acta Juridica 41-57

Le Roux 2014 ILJ

Le Roux R "Employment: A Dodo or Simply Living Dangerously?" 2014 ILJ 30-46

Madebwe 2014 Midlands State U L Rev

Madebwe $\mathrm{T}$ "Constitutionalism and the New Zimbabwean Constitution" 2014 Midlands State U L Rev 6-19

Madhuku Labour Law in Zimbabwe

Madhuku L Labour Law in Zimbabwe (Weaver Press Harare 2015)

Malan 2012 De Jure

Malan K "The Rule of Law Versus Decisionism in the South African Constitutional Discourse" 2012 De Jure 272-305

Mucheche 2017 ZELJ

Mucheche C "Amendments to the Zimbabwean Labour Act (Chapter 28:01) and their Implications on the Employment Relationship: A Review of Some Critical Sections of the Labour Amendment Act 5 of 2015" 2017 ZELJ 1426 
Newaj Unfair Labour Practice in South African Labour Law

Newaj K An Appraisal of the Provision of "Benefits" as an Unfair Labour Practice in South African Labour Law (LLD-thesis University of Pretoria 2019)

Norton 2009 ILJ

Norton D "What is (and What isn't) a Constitutional Matter in the Context of Labour Law" 2009 ILJ 772-790

Poolman Principles of Unfair Labour Practice

Poolman T Principles of Unfair Labour Practice (Juta Cape Town 1985)

Reichman and Mureinik 1980 ILJ

Reichman A and Mureinik E "Unfair Labour Practices" 1980 ILJ 1-22

Reid and Visser Private Law and Human Rights

Reid E and Visser D Private Law and Human Rights: Bringing Rights Home in Scotland and South Africa (Edinburgh University Press Edinburgh 2014)

Robertson and Sams 1972 MLR

Robertson N and Sams IK "The New Legal Framework for Britain's Industrial Relations" 1972 MLR 48-52

Roux 2009 Stell LR

Roux $T$ "Transformative Constitutionalism and the Best Interpretation of the South African Constitution: Distinction without Difference?" 2009 Stell LR 258-285

Rycroft 1996 S Afr Hum Rts Yrbk

Rycroft A "Labour" 1996 S Afr Hum Rts Yrbk 138-152

Smith 1961 Marq L Rev

Smith JC "Unfair Labour Practices in Wisconsin" 1961 Marq L Rev 223-265

Travis 1948 SMU L Rev

Travis A "Unfair Labour Practices" 1948 SMU L Rev 194-215

Tsabora and Kasuso 2017 ILJ

Tsabora $\mathrm{J}$ and Kasuso TG "Reflections on the Constitutionalising of Individual Labour Law and Labour Rights in Zimbabwe" 2017 ILJ 43-62

Van Marle 2009 Stell LR

Van Marle K "Transformative Constitutionalism as/and Critique" 2009 Stell LR 286-301 
Van Niekerk et al Law@work

Van Niekerk A et al Law@work $3^{\text {rd }}$ ed (LexisNexis Durban 2015)

Case law

Agricultural Bank of Zimbabwe Ltd v Machingaifa 2008 1 ZLR 244 (S)

Air Zimbabwe (Pvt) Ltd v Zendera 20021 ZLR 132 (S)

Association of Professional Teachers v Minister of Education 199516 ILJ 1048 (IC)

Chawira v Minister, Justice Legal and Parliamentary Affairs (CCZ 3 of 2017, Constitutional Application CCZ 47 of 2015, Constitutional Application CCZ 50 of 2015) [2017] ZWCC 3 (20 March 2017)

Chirasasa v Nhamo 20032 ZLR 206 (S)

City of Gweru v Munyari (62/04) (SC 15 of 2005, Civil Appeal 162 of 2004) [2005] ZWSC 15 (01 June 2005)

Ex parte Chairperson of the Constitutional Assembly: In re Certification of the Constitution of the Republic of South Africa, 1996199617 ILJ 821 (CC)

Gcaba v Minister for Safety and Security 20101 SA 238 (CC)

Greatermans Stores (1979) (Pvt) Ltd v Minister of Public Service, Labour and Social Welfare (CCZ 2/18)

Guruva v Traffic Safety Council of Zimbabwe 20091 ZLR 58 (S)

Katsande v Infrastructure Development Bank of Zimbabwe 20171 ZLR 670 (C)

Magurure v Cargo Carriers International Haulers (Pvt) Ltd 20162 ZLR 788 (C)

MEC for Education, Kwa-Zulu Natal v Pillay 20081 SA 474 (CC)

Moyo v Sgt Chacha (CCZ 19 of 2017, Constitutional Application CCZ 73 of 2016) [2017] ZWCC 19 (20 September 2017)

Mudarikwa v Director of Housing and Community Services 2007 1 ZLR 41 (S) 
Mushapaidze v St Annes Hospital (CCZ 18 of 2017, Constitutional Application CCZ 20 of 2014) [2017] ZWCC 18 (20 September 2017)

Muwenga v PTC 19972 ZLR 483 (S)

National Educational Health and Allied Workers Union v CCMA 200728 ILJ 1223 (LAC)

National Education Health and Allied Workers Union v University of Cape Town 200324 ILJ 95 (CC)

National Entitled Workers Union v CCMA 20042 BLLR 165 (LC)

Nyamande v Zuva Petroleum (Pvt) Ltd 20152 ZLR 157 (S)

Rainbow Tourism Group v Nkomo 20152 ZLR 248 (S)

Taylor v Minister of Higher Education 19962 ZLR 772 (S)

Sagandira v Makoni Rural District Council (SC 70 of 2014, Civil Appeal SC 264 of 2012) [2014] ZWSC 70 (15 September 2014)

Samanyau v Fleximail (Pvt) Ltd (HH 108/11)

Stewart v The Vice-Chancellor of the University of Zimbabwe (SC 97/01)

\section{Legislation}

Constitution of the Republic of South Africa, 1996

Constitution of Zimbabwe, 1980

Constitution of Zimbabwe Amendment (No 20) Act 2013

Employment Act 13 of 1980

Health Service Act (Chapter 15:16)

Industrial Relations (Amendment) Act 95 of 1982

Industrial Relations Act, 1971

Labour Act (Chapter 28:01)

Labour (Amendment) Act 5 of 2015 
Labour Relations Act 28 of 1956

Labour Relations Act 16 of 1985

Labour Relations Act 66 of 1995

Labour Relations (Amendment) Act 17 of 2002

Labour Relations (Amendment) Act 83 of 1988

Labour Relations (Amendment) Act 9 of 1991

Minimum Wages Act, 1980

National Labor Relations Act, 1935

Public Service Act (Chapter 16:04)

\section{List of Abbreviations}

AHRLJ

BJELL

CCMA

CLLPJ

ILJ

ILO

IRLJ

LA

LRA

Marq L Rev

MLR

Midlands State U L Rev

$S$ Afr Hum Rts Yrbk

SMU L Rev

Stell LR

UK

USA

ZELJ
African Human Rights Law Journal

Berkeley Journal of Employment and Labor

Law

Commission for Conciliation Mediation and Arbitration

Comparative Labour Law and Policy Journal

Industrial Law Journal

International Labour Organisation

Industrial Relations Law Journal

Labour Ac (Chapter 28:01)

Labour Relations Act 16 of 1985

Marquette Law Review

Monthly Labour Review

Midlands State University Law Review

South African Human Rights Yearbook

SMU Law Review

Stellenbosch Law Review

United Kingdom

United States of America

Zimbabwe Electronic Law Journal 